(C) 2018 International Journal of Nursing and Midwifery Science(IJNMS)

This is an Open Access article distributed under the terms of the Creative CommonsAttribution 4.0 International License which permits unrestricted noncommercial use, distribution, and reproduction in any medium, provided the original work is properly cited.

\title{
THE INFLUENCE OF DIABETIC FOOT GYMNASTIC TO BODY BALANCE OF ELDERLY DIABETES MELLITUS PATIENTS IN GATOEL MOJOKERTO HOSPITAL DIABETIC CLUB
}

\author{
MUHITH ABDUL ${ }^{1}$, HANNAN MUJIB ${ }^{2}$, DWIHELYNARTI $\mathbf{S}^{3}$, M. HIMAWAN $\mathbf{S}^{4}$, \\ TATIK SUTARTI ${ }^{5}$, ISMAWATI $\mathrm{S}^{6}$ \\ ( ${ }^{1}$ Associate Professor in Nursing Department of STIKes Majapahit;) \\ $\left({ }^{2}\right.$ Lecturer in Faculty of Nursing Comunity Universitas wiraraja Sumenep, Indonesia) \\ ${ }^{3}$ Lecturer in Public Health Department of STIKes Majapahit \\ ${ }^{4}$ Lecturer in Public Health Department of STIKes Majapahit \\ ${ }^{5}$ Lecturer in Public Health Department of STIKIP PGRI PACITAN \\ ${ }^{6}$ The Student in Nursing Department of STIKesMajapahit
}

Email correspondence: abdulmuhith1979@gmail.com, mujib@wiraraja.ac.id

\section{ABSTRACT}

Diabetes mellitus suffers from insulin deficiency which inhibited the transfer of glucose to cells in body tissues that cause starvation cells an in the increase in glucose in the blood that leads to muscle weakness thus disrupt the body's balance and increase the risk of falling. Diabetic foot exercises aim to improved blood circulation in the feet of people with diabetes mellitus, so that nutrient smoothly to the network. The purpose of this study to determine the effect of diabetic foot gymnastics on body balance older adults with diabetes mellitus in Diabetic Club Gatoel Hospital Mojokerto in the 27 February - 25 March 2017. This research used a Quasy Experimental method with PretestPosttest with Control Group Design. The sampling technique used Simple Random Sampling with the sample of 17 respondents for the control group and 17 respondents for the intervention group. Wilcoxon Signed Rank Test obtained p-value $0,000<0,05$ concluded that there is an influence of diabetic foot exercises on body balance in older adults with diabetes mellitus in Diabetic Club Gatoel Hospital Mojokerto. The study recommended that older adults with diabetes mellitus are expected to take advantage of diabetic foot exercises as an effort to improve the balance of the body to reduce the incidence of fall.

\section{Keywords}

Diabetic Foot Exercises, Body Balance, Diabetes Mellitus 


\section{INTRODUCTION}

Elderly is a part of family members and communities that are increasing in number in line with increasing life expectancy. The older a person, he will experience a setback, especially in the field of physical ability, which can lead to a decrease in social roles that lead to dependence. In old age, a right balance is needed by someone in supporting their daily mobility(Abdul Muhit, 2016).

Demographically, the proportion of the elderly population in the world in 2013 was $(13.4 \%)$, predicted to increase in 2050 reaching $(25.3 \%)$ and in 2100 reaching (35.1\%). Indonesia is among the top five countries with the highest number of older adults in the world. Based on the 2015 population census, the number of elderly population in Indonesia is 23.992 million people $(9.77 \%)$ and is estimated in 2020 ; the number will reach 28.882 million people $(11.34 \%)$. The most significant proportion of elderly in three provinces is Yogyakarta (13.05\%), Central Java (11.11\%), East Java (10.96\%), and Bali $(10.05 \%)$. (BPS, 2015). The proportion of diabetes mellitus sufferers in Indonesia at the age of 55-64 years was (11.50\%), at the age of $65-74$ years $(13.20 \%)$. The prevalence of diabetes mellitus based on physician diagnosis and symptoms increases with age, in East Java (2.5\%) and increases in age 55-64 years $(5.5 \%)$ (Ministry of Health RI, 2014). In Mojokerto City the percentage of the elderly population was $(9.94 \%)$, with the rate of men $(9.26 \%)$ and women $(10.62 \%)$ and an estimated $20 \%$ of older adults suffered from diabetes mellitus(Badan Pusat Statistika, 2015). Based on the results of a preliminary study on December 6, 2016, at 11.00 WIB in the Diabetic Club of Gatoel Mojokerto Hospital, there were 50 older adults with diabetes mellitus who received gymnastics.
And 10 elderly diabetics complain of foot tingling and numbness.

Diabetes mellitus is a significant risk factor for impaired lower limb function, balance disorders, and mobility. Compared to other older adults, the risk of physical limitations is 2-3 times that of older adults with diabetes mellitus, and this risk is higher in women. The impact of all this is that more senior women with diabetes mellitus experience falls and fractures. (Indra Kurniawan, 2010). Balance in the elderly also experienced a setback. The existence of a balance disorder in the elderly will cause falls in the elderly(Oktarianti, 2014).

Several studies mentioned in his research in Magelang that there was an effect of diabetic foot gymnastics on foot sensitivity and blood sugar levels in the elderly aggregate of diabetes mellitus, foot sensitivity was better in the elderly after being given leg exercises(Priyanto, 2013). Also, other researchers regarding the influence of elderly gymnastics on body balance in the elderly in the Dajan Bingin Sading environment showed a significant change between the balance of the old body before and after being given gymnastics for 35 minutes in the afternoon for four weeks. This is evident from the improvement of the balance of the old body after being given gymnastics for the elderly(Valentine, 2016).Also, hatha yoga modification training and tai chi exercise can also improve balance.

Based on the background description, one physical activity that deserves to be recommended and designed for the elderly to exercise body balance is diabetic foot exercises. Diabetic foot exercises are activities or exercises carried out by the elderly who suffer from diabetes mellitus to prevent injury and help to improve the circulation of the legs. Also, diabetic foot exercises are also useful to 
strengthen the small muscles of the legs, prevent foot deformities, increase calf muscles and thigh muscles, and overcome the limitations of joint movements(Setyoadi, 2011). Physical exercise of diabetic foot exercises keeps it moving because by moving indirectly it will keep the muscles and joints to regulate the balance of both legs and strengthen joint muscles to reduce the risk of falling in the elderly with diabetes. And the risk of other complications(Adit, 2015). Diabetic foot exercises are carried out 2-3 times a week for 15 minutes to get effective results(Kurnirius, 2011).

The research objective was to analyze the effect of diabetic foot gymnastics on the body balance of elderly people with diabetes mellitus in the Diabetic Club of Gatoel Hospital in Mojokerto.

\section{MATERIALS AND METHODS}

This research was conducted using the experimental Quasy design with PrePosttest design with Control Group Design. This research was conducted at the Diabetic Club of Gatoel Mojokerto Hospital on 27 February - 25 March 2017. The population in this study were 50 elderly people with diabetes mellitus in the Diabetic Club of Gatoel Mojokerto Hospital and sampling techniques with Simple Random Sampling as many as 17 samples respondents for the control group and 17 respondents for the intervention group.

Measurements were carried out in two ways, namely pretest and posttest, a pretest was before being given diabetic foot exercises using Berg Balance Scale (BBS), and posttest was given diabetic foot exercises using Berg Balance Scale (BBS) 2 times a week for four weeks.
RESULTS

Table 1. Distribution of Pretest Body Balance Frequency in Control Groups and

\begin{tabular}{|c|c|c|c|c|c|c|c|c|c|}
\hline & \multirow{3}{*}{$\begin{array}{c}\text { Grou } \\
\mathbf{p}\end{array}$} & \multicolumn{6}{|c|}{ Body Balance } & \multirow{2}{*}{\multicolumn{2}{|c|}{ Total }} \\
\hline & & \multicolumn{2}{|c|}{ Good } & \multicolumn{2}{|c|}{$\begin{array}{c}\text { Medi } \\
\text { um }\end{array}$} & \multicolumn{2}{|c|}{ High } & & \\
\hline & & $\mathbf{f}$ & $\%$ & $\mathbf{f}$ & $\%$ & $\mathbf{F}$ & $\%$ & $\mathbf{F}$ & $\%$ \\
\hline $\begin{array}{l}P \\
r e \\
T\end{array}$ & $\begin{array}{l}\text { Contr } \\
\text { ol }\end{array}$ & $\begin{array}{l}1 \\
1\end{array}$ & $\begin{array}{l}6 \\
4, \\
7\end{array}$ & 4 & $\begin{array}{l}2 \\
3, \\
5\end{array}$ & 2 & $\begin{array}{l}1 \\
1, \\
8\end{array}$ & $\begin{array}{l}1 \\
7\end{array}$ & $\begin{array}{l}1 \\
0 \\
0\end{array}$ \\
\hline $\begin{array}{l}e s \\
t\end{array}$ & $\begin{array}{l}\text { Interv } \\
\text { ention }\end{array}$ & $\begin{array}{l}1 \\
0\end{array}$ & $\begin{array}{l}5 \\
8, \\
8\end{array}$ & 6 & $\begin{array}{l}3 \\
5, \\
2\end{array}$ & 1 & 6 & $\begin{array}{l}1 \\
7\end{array}$ & $\begin{array}{l}1 \\
0 \\
0\end{array}$ \\
\hline & Total & 1 & $\begin{array}{l}6 \\
2\end{array}$ & $\begin{array}{l}1 \\
0\end{array}$ & $\begin{array}{l}2 \\
9\end{array}$ & 3 & 9 & $\begin{array}{l}3 \\
4\end{array}$ & $\begin{array}{l}1 \\
0 \\
0\end{array}$ \\
\hline
\end{tabular}

\section{Intervention Groups}

Based on table 1. shows that the pre-test in the intervention group more than $50 \%$ of respondents have a good body balance that is ten respondents $(58.8 \%)$. Whereas in the pre-test control group, the majority of respondents had a good body balance as many as 11 respondents $(64.7 \%)$. Based on the research data, the body balance of respondents with diabetes mellitus before intervention tends to be in the medium category. 
Table 2. Distribution of Posttest Body

Balance Frequency in

Control Groups and

Intervention Groups

\begin{tabular}{|c|c|c|c|c|c|c|c|c|c|}
\hline & \multirow{3}{*}{$\begin{array}{l}\text { Grou } \\
\text { p }\end{array}$} & \multicolumn{6}{|c|}{ Body Balance } & \multirow{2}{*}{\multicolumn{2}{|c|}{ Total }} \\
\hline & & \multicolumn{2}{|c|}{ Good } & \multicolumn{2}{|c|}{$\begin{array}{c}\text { Medi } \\
\text { um }\end{array}$} & \multicolumn{2}{|c|}{$\begin{array}{c}\text { Hig } \\
\text { h }\end{array}$} & & \\
\hline & & $\mathbf{F}$ & $\%$ & $\mathbf{f}$ & $\%$ & $\mathbf{F}$ & $\%$ & $\mathbf{F}$ & $\%$ \\
\hline $\begin{array}{c}P \\
o s \\
t\end{array}$ & $\begin{array}{l}\text { Contr } \\
\text { ol }\end{array}$ & $\begin{array}{l}1 \\
0\end{array}$ & $\begin{array}{l}5 \\
8, \\
8\end{array}$ & 6 & $\begin{array}{l}3 \\
5, \\
2\end{array}$ & 1 & 6 & 7 & $\begin{array}{l}1 \\
0 \\
0\end{array}$ \\
\hline es & $\begin{array}{l}\text { Interv } \\
\text { ention }\end{array}$ & $\begin{array}{l}1 \\
5\end{array}$ & $\begin{array}{l}8 \\
8, \\
2\end{array}$ & 2 & $\begin{array}{l}1 \\
1, \\
8\end{array}$ & 0 & 0 & 7 & $\begin{array}{l}1 \\
0 \\
0\end{array}$ \\
\hline & Total & $\begin{array}{l}2 \\
5\end{array}$ & $\begin{array}{l}7 \\
3, \\
5\end{array}$ & 8 & $\begin{array}{l}2 \\
3, \\
5\end{array}$ & & 3 & 4 & $\begin{array}{l}1 \\
0 \\
0\end{array}$ \\
\hline
\end{tabular}

Based on table 2. shows that in the intervention group almost all of the posttest respondents have a good body balance that is 15 respondents $(88.2 \%)$. Whereas in the control group most of the respondents in the post-test had good body balance $(58.8 \%)$. Based on research data it was found that respondents who did diabetic foot exercises two times a week experienced a significant increase in body balance compared to respondents who did not do diabetic foot exercises.
Table 3. Frequency Distribution of the Effects of Diabetic Foot Gymnastics on Body Balance in the Elderly Patients with Diabetes Mellitus in the Diabetic Club of the Gatoel Mojokerto Hospital on

\begin{tabular}{|c|c|c|c|c|c|c|c|c|c|}
\hline \multirow{3}{*}{$\begin{array}{l}\mathbf{N} \\
\text { o. }\end{array}$} & \multirow{3}{*}{$\begin{array}{c}\text { Bod } \\
\mathbf{y} \\
\text { Bal } \\
\text { anc } \\
\text { e }\end{array}$} & \multicolumn{4}{|c|}{ Control } & \multicolumn{4}{|c|}{ Intervention } \\
\hline & & & & & & & & & $\begin{array}{l}\text { ost } \\
\text { est }\end{array}$ \\
\hline & & f & $\%$ & f & $\%$ & f & $\%$ & f & $\%$ \\
\hline 1 . & $\begin{array}{c}\text { Goo } \\
\mathrm{d}\end{array}$ & $\begin{array}{l}1 \\
1\end{array}$ & $\begin{array}{c}6 \\
4, \\
7\end{array}$ & $\begin{array}{l}1 \\
0\end{array}$ & $\begin{array}{l}8, \\
8\end{array}$ & $\begin{array}{l}1 \\
0\end{array}$ & $\begin{array}{l}5 \\
8, \\
8\end{array}$ & $\begin{array}{l}1 \\
5\end{array}$ & $\begin{array}{l}8 \\
8, \\
2\end{array}$ \\
\hline 2. & $\begin{array}{l}\text { Med } \\
\text { ium }\end{array}$ & 4 & $\begin{array}{l}2 \\
3, \\
5\end{array}$ & 6 & $\begin{array}{l}3 \\
5, \\
2\end{array}$ & 6 & $\begin{array}{l}3 \\
5, \\
2\end{array}$ & 2 & $\begin{array}{l}1 \\
1, \\
8\end{array}$ \\
\hline
\end{tabular}

\begin{tabular}{|c|c|c|c|c|c|c|c|c|c|}
\hline 3. & $\begin{array}{c}\text { Hig } \\
\text { h }\end{array}$ & 2 & $\begin{array}{l}1 \\
1, \\
8\end{array}$ & 1 & 6 & 1 & 6 & 0 & 0 \\
\hline & Tota & 1 & 1 & 1 & 1 & 1 & 1 & 1 & 1 \\
\hline & 1 & 7 & 0 & 7 & 0 & 7 & 0 & 7 & 0 \\
\hline & & & 0 & & 0 & & 0 & & 0 \\
\hline
\end{tabular}

\begin{tabular}{|c|c|c|}
\hline $\mathrm{p}$ & Uji Wilcoxon & Uji Wilcoxon \\
\hline valu & Signed Rank & Signed Rank \\
\hline$e$ & Test $=0,131$ & Test $=0,000$ \\
\hline
\end{tabular}

Based on table 3. using the Wilcoxon Signed Rank Test test in the control group with a significance value of $0.131>0.05$ indicating that there is no effect of diabetic foot gymnastics on body balance in elderly diabetics in the Diabetic Club of Gatoel Hospital in Mojokerto. While the Wilcoxon Signed Rank Test test in the intervention group with a significance value of 0.000 or $p<0.05$, which means that $\mathrm{H} 1$ is accepted means that there is an effect of diabetic foot 
gymnastics on body balance in elderly people with diabetes mellitus in the Diabetic Club of Gatoel Hospital in Mojokerto.

\section{DISCUSSION}

\section{Body Balance Before Given Diabetic Foot Gymnastics in the Control Group and Intervention Group}

Based on table 1. research data obtained the body balance of respondents in the control group and intervention with diabetes mellitus before intervention tends to be in the medium category. The results showed that almost half of the respondents in the treatment group had a moderate body balance of 6 respondents $(35.2 \%)$ and the overall respondents in the control group had a good body balance of 11 respondents (64.7\%).(Muhid, 2010)

The decline in physical ability in the elderly is strengthened by the theory of Pudjiastuti (2003) saying that the elderly experience problems in their motor skills, namely a decrease in strength and energy. Gait disturbances, weakness of lower extremities and joint damage are morphological changes of the muscles. Morphological changes of muscles cause functional changes in muscles, elasticity, and flexibility of muscles: a speed of reaction time, relaxation and functional work. Furthermore, decreased function and muscle strength will result in a decrease or decline in the ability to maintain body balance - obstacles in sitting motion to standing increased the risk of falls, changes in posture. Problems with the ability to move and function, are closely related to muscle strength that is individual in the elderly(Muhid, 2010). With sports such as jogging, running, lifting weights, badminton, tennis or other sports will maintain the bone density of the elderly. Also, exercise can also strengthen the muscles of the elderly and help balance the posture so that the possibility of fracture (fracture) is smaller(Abdul Muhith, 2015).

Patients with diabetes mellitus have characteristics of hyperglycemia; high blood sugar levels cause various disorders of the somatosensory system (visual, vestibular, proprioceptive) and motoric (musculoskeletal, muscle, soft tissue joints) which can interfere with the balance system thereby increasing the risk of falls. Also, diabetics have insulin deficiency which inhibits the transfer of glucose to cells in body tissues which causes cells to starve and an increase in glucose in the blood.

This creates obstacles in perfusion to muscle tissue which will result in muscle tissue getting less oxygen and nutrients which causes cells to lack the material for metabolism so that the energy produced decreases which result in the onset of weakness and can further result in muscle atrophy. Muscle weakness causes interference in static and dynamic body balance. These disorders will cause the body to falter and become unstable, increasing the risk of falls and fractures. (Mauk, 2010).

In general, the balance of the body is also affected by daily physical activity, physical activity carried out daily can train the lower extremities, namely both feet to always maintain balance when doing activities of standing, moving, and walking so that it has an effect on the balance of the elderly body of people with diabetes mellitus.The results of Maryam, et al. (2009) study stated that elderly people who have activities that are less risky of the occurrence of balance disorders than the elderly whose activities are good. Physical activity can be done at leisure, the scope of work, and daily routine activities such as 
homework, gardening, hobbies, recreation, and sports(Andriyani Ayu, 2012). This is reinforced by the opinion of Lord et al. (2007) which states that the average incidence of falls in elderly women is $40 \%$ while men $38 \%$ and will continue to increase at the age above 65 years. This event can be caused by reduced muscle strength in elderly women and lack of ability of elderly women to restore body stability. Elderly women also experience muscle weakness in the lower extremities so that they cannot support their weight(Andriyani Ayu, 2012).

The results of the analysis of the researcher, respondents who participated in this study were aged 60-74 years old who had entered the elderly but were still active in gymnastics activities, and the majority of respondents were mostly female. The risk of physical limitations in elderly people with diabetes mellitus is greater in women; the same effect is that more elderly women with diabetes mellitus experience falls and fractures.

\section{Body Balance After Given Diabetic Foot Gymnastics in the Control Group and Intervention Group.}

Based on the research data in table 2. it was found that almost all respondents in the treatment group experienced an increase in body balance to be good, namely 15 respondents $(88.2 \%)$ while almost half of the respondents in the control group had a moderate body balance, namely six respondents (35.2\%). This means that respondents who did diabetic foot exercises two times a week experienced a significant increase in body balance compared to respondents who did not do diabetic foot exercises.

The results of this study are in line with the research in Switzerland by Rocher cited by Wibisono in patients with diabetes mellitus with neuropathy, the results of irregular exercise research are at risk of developing diabetic ulcer four times higher than regular exercise(Priyanto, 2013). The results of this study are consistent with a statement explaining that the physiological effects of foot exercises routinely will achieve simultaneous or separate effects. Mechanical effects occur directly from the muscles or tissues which are intentionally carried out on diabetic foot exercises that stimulate blood circulation; the muscles become softer and more flexible. So that with an increase in peripheral blood circulation can minimize muscle weakness and does not cause disturbance to the body's balance(Sudoyo, 2009). Six diabetic feet is one form of skill in which to achieve an increase requires a long and regular time and must be practiced.

This is consistent with the study of Sahar (2002) which states that there is a significant increase in skills after six months of training. Similarly, research by Barnett et al. (2003) found that physical exercise carried out 1 hour per week for one year could reduce damage by 40\%(Priyanto, 2013).Therefore, diabetic foot exercises that are carried out regularly and in a balanced manner can have a positive impact on elderly people with diabetes mellitus, especially those who experience body balance disorders.

The results of the analysis of the researcher, the effect of diabetic foot gymnastics can be felt by the respondents after the respondent did diabetic foot exercises for two times a week, where the respondents felt the muscles in the lower extremities were not stiff anymore and the respondents felt comfortable in their activities.

3. The Effect of Diabetic Foot Gymnastics on Body Balance in the Elderly Patients with Diabetes Mellitus in the Diabetic Club of Gatoel Hospital in Mojokerto. 
Based on table 3. the data of respondents in the intervention group experienced an increase in body balance from the medium to good category. This illustrates that the elderly who were given diabetic foot exercises had relatively better body balance than the elderly who did not receive diabetic foot exercises. The results of the above study reinforce the research of Balleard et al. (2004) which shows a significant increase of 14 items of balance assessment instruments due to gymnastics performed so that the exercise training program can improve the balance and strength of the legs(Setyoadi, 2011).

The results of the above research are in line with the theory which states that the goal obtained after doing diabetic foot exercises is to improve blood circulation in the legs of patients with diabetes mellitus so that the nutrition is smooth. The motion in the diabetic foot gymnastics as presented in the 3rd National Diabetes Educator Training Camp in 2005 can help improve blood circulation at the foot. It can reduce complaints from sensory neuropathy such as feeling achy, tingling in the legs. Diabetic foot exercises are an alternative for diabetes mellitus patients to increase blood flow and improve blood circulation. This makes more capillary open so that more insulin receptors are available and active. This condition will make it easier for nerves to receive nutrients and oxygen so that they can improve their function. Diabetic foot exercises can make contractions of the muscles that cause the opening of ion channels, especially positive ions which can facilitate the delivery of nerve impulses(Camelia, 2016). The right portion of diabetic foot exercise is about 10-15 minutes, preferably 2-3 times a week to get effective results. Exercises that are carried out regularly will show optimal results(Kurnirius, 2011).
The results of the analysis of the researchers, the increase in body balance from the medium to good after diabetic foot exercises in elderly people with diabetes mellitus in the intervention group in the Diabetic Club of Gatoel Hospital in Mojokerto was due to the respondents doing diabetic foot exercises correctly and regularly according to the movements determined by the frequency of exercise 2 times a week for less than 10-15 minutes in 8 weeks. Diabetic foot exercises physical exercise can keep it moving because by moving indirectly it will maintain the muscles and joints to regulate the balance of both legs and strengthen joint muscles as a way to reduce the risk of falling in the elderly and the risk of other complications. This will improve the body's balance, especially in the elderly with diabetes mellitus. This condition is supported by the results of research conducted in the Diabetic Club of Gatoel Mojokerto Hospital which showed an increase in the average body balance in the intervention group which performed diabetic foot exercises compared to the control group who did not do diabetic foot exercises.

Researchers assume that if elderly people with diabetes mellitus continue to perform their daily activities in accordance with the activities in their environment such as diabetic foot exercises 2 times a week, gardening, recitation activities, joyful stage, and regular skills are expected to increase the strength of lower extremity and balance, so that prevent the risk of falling. The results of this study indicate that diabetic foot exercises can increase or reduce body balance disorders. This is because the provision of diabetic foot training is one way to regulate the balance in the legs and can increase activity for the falls. 


\section{CONCLUSIONS}

Based on the results of the discussion about the effect of diabetic foot gymnastics on the balance of the body between groups that apply diabetic foot exercises and not in elderly diabetes mellitus can be concluded that :

1. The balance of the body before being given diabetic foot exercises in the control group and the intervention group in the elderly with diabetes mellitus in the Diabetic Club of Gatoel Mojokerto Hospital tend to be in the medium category.

2. The balance of the body after being given diabetic foot exercises in the control group and the intervention group in the elderly with diabetes mellitus in the Diabetic Club Gatoel Mojokerto Hospital experienced an increase from the moderate to the good category in the intervention group.

3. There is an effect of diabetic foot exercises on body balance in elderly people with diabetes mellitus in the Diabetic Club of Gatoel Hospital in Mojokerto.

\section{REFERENCES}

Abdul Muhit, S. S. (2016). Gerontik Nursing Education (Theory and application). Yogyakarta: Andi.

Abdul Muhith. (2015). Pendidikan Keperawatan Jiwa (Teori dan Aplikasi). Yogyakarta: Andi.

Adit, P. (2015). Peningkatan Keseimbangan Postural Menggunakan Pengukuran Berg Balance Scale (BBS) Pada Lansia Di Sasana Panti Mulyo Sragen. Journal of Sports Science and Fitness.

Andriyani Ayu, A. (2012). Hubungan Faktor Internal dan Eksternal dengan Keseimbangan Lansia di Desa
Pamijen Sokaraja Banyumas. UI.

Badan Pusat Statistika. (2015). Profil penduduk lanjut usia Jawa Timur 2015. Surabaya.

Camelia, S. dan S. (2016). Senam Kaki Efektif Mengobati Neuropati Diabetik Pada Penderita Diabetes Mellitus. Jurnal Kesehatan, VII(3).

Kurnirius, H. (2011). Pengaruh Senam Kaki Terhadap Sirkulasi Darah Kaki Pada Pasien Penderita Diabetes Mellitus Di Ruang Penyakit Dalam RSU Dr. Piringadi. Medan.

Muhid, A. (2010). "Kemampuan Fungsional Lancia di UPT Panti Werdha Majapahit Mojokerto. Jurnal Hospital Majapahit, 2(2).

Oktarianti, I. K. (2014). Gambaran Kemampuan kognitif dan keseimbangan pada wanita lanjut usia. Jurnal Ilmiah Keperawatan, 2(1).

Priyanto, S. (2013). Pengaruh senam kaki terhadap sensitifitas kaki dan kadar gula Darah pada Aggregat lansia diabetes melitus di Magelang, Jawa Barat. In Proseding Konferensi Nasional PPNI.

Setyoadi, K. (2011). Senam dapat meningkatkan keseimbangan tubuh lansia di Yayasan Gerontologi Kecamatan Wajak Kabupaten Malang. Jurnal Ilmu Keperawatan, 1(1).

Sudoyo. (2009). Buku ajar ilmu penyakit dalam. Jakarta: Departemen Ilmu Penyakit Dalam.

Valentine, M. (2016). Pengaruh Senam Kaki Diabetik Terhadap Intensitas Nyeri Neuropati Diabetik Pada Penderita Diabetes Mellitus Tipe 2 di RSUD Ungaran. Jurnal Keperawatan Coping Ners. 